\title{
THE RESPONSE OF ZIMBABWE TOBACCO EXPORTS TO REAL EXCHANGE RATES VOLATILITY: 1980-2019
}

\author{
Knowledge Mutodi ${ }^{1}$, Eugine Tafadzwa Maziriri ${ }^{2}$, Tinashe Chuchu ${ }^{3 凶}$ \\ ${ }^{1}$ University of Zimbabwe, Zimbabwe \\ ${ }^{2}$ University of the Free State, South Africa \\ ${ }^{3}$ University of Pretoria, South Africa
}

\begin{abstract}
The focus of this study was on investigating the response of tobacco exports to real exchange rates and real exchange rate volatility and other factors in Zimbabwe using secondary data spanning from 1980 to 2019. Bilateral nominal exchange rates and time-variant weights of Zimbabwe's 10 major trading partners were calculated and used to compute the real exchange rate index. The time-dependent weighting system was used to better represent the evolution of trade patterns in the index. The arithmetic method was employed for computing the index. Generalized autoregressive conditional heteroskedasticity $(\mathrm{GARCH})$ and autoregressive conditional heteroscedasticity $(\mathrm{ARCH})$ models were used to generate the real exchange rate volatility index. The export response function was adopted as the tobacco exports response model. The variables in the tobacco exports response model were the realworld Gross Domestic Product (GDP), real exchange rate, terms of trade, real exchange rate volatility and dollarization. A vector error correction model (VECM) was used to estimate the response of tobacco exports to real exchange rate, real exchange rate volatility and other factors. The VECM results indicated that real world GDP was insignificant in both the short and long run. In the long run, the real exchange rate appreciation had a negative impact on tobacco exports. Conversely, in the short run, the depreciation of real exchange rate had a positive impact on tobacco exports. Hence, the government has to adopt other mechanisms that reduce uncertain movements of exchange rates.
\end{abstract}

Keywords: real exchange rate (RER), real exchange rate volatility (RERV), vector error correction model (VECM)

\section{INTRODUCTION}

Zimbabwe is a small open economy (Nyanga et al., 2020; Sithole, 1996). Its ratio of gross domestic product (GDP) to world GDP was 0.03 in 2014 and 0.02 in 2015 (World Bank, 2016). In 1960-2018, the average GDP per capita in Zimbabwe was USD 1220.33 (Trade Economics, 2020). Furthermore, Zimbabwe reached an all-time highest increase in GDP of USD 1524.30 in 1998 and a record low of USD 725.60 in 2008 (Trade Economics, 2020). However, in 2015, imports and exports as a percentage of GDP were $48.78 \%$ and $26.25 \%$, respectively (ZimTrade, 2015). Zimbabwe's major exports are minerals followed by agriculture. Among these major exports, the share of minerals in total exports in 2012 was $64 \%$ of which $26.9 \%$ were diamonds, $26.1 \%$ was gold and $0.7 \%$ were nickel and others. The share of agricultural exports in total exports in 2009 was $35 \%$, of which $61 \%$ was tobacco, $22 \%$ was cotton, $11 \%$ was raw sugar and $3 \%$ were horticultural products. Tobacco as the dominant cash and export crop resulted in USD 855 million of foreign exchange earnings in 2015 and contributed about $26 \%$ to agricultural GDP in 2009 (Government of Zimbabwe, 2016; Tobacco Industry..., 2015). The major imports are diesel fuel, unleaded gas, maize, wheat, crude soya bean oil and others. The share of fuels and cereals in 2014 imports was $25 \%$ and $5 \%$, respectively (ZimTrade, 2015). However, agricultural

$凶$ Tinashe Chuchu, Department of Marketing Management, Faculty of Economic and Management Sciences, University of Pretoria, e-mail: tinashe.chuchu@up.ac.za, https://orcid.org/0000-0001-7325-8932 
imports have recently surged as the share of food imports in merchandise imports has increased from $14.26 \%$ in 2013 to $15.14 \%$ in 2015 (Buigut, 2015). Low agricultural food production has increased the appetite for food imports and resulted in a general economic dependence on imports.

Large depreciations and high volatility of the real exchange rate were connected to major structural shifts, namely the economic structural adjustment (ESAP) in 1992 and particularly the land reform in 2000. Under the dollarization policy, the real exchange rate appreciated against Zimbabwe's major trading partners. This signaled a loss of external competitiveness of Zimbabwean exports. The terms of trade were significant in both the short and long run. The real exchange rate volatility indicated that the impact of high fluctuations on tobacco exports was negative in the short run and positive in the long run. Dollarization was significant in the short run and insignificant in the long run. Hence, appreciation and random movements of the real exchange rate were found to affect the exports of tobacco, a dominant export commodity in agriculture. The study recommends the government to devalue the real exchange rate without changing the nominal exchange rate value for exports to remain competitive in both the domestic and international market. Also, the authorities can promote futures markets to hedge against uncertain movements of exchange rates. Terms of trade can be improved by raising taxes on importable goods. High interest rates can be set to attract high capital inflows to reduce tight liquidity conditions in the economy.

Over the past two decades, the economy has witnessed great changes in production volumes and general patterns of trade. This transformation has been a result of the introduction of several micro- and macroeconomic policy changes (World Bank, 2016). However, the introduction of these policies has seen major structural shifts in the economy. The major causes of structural shifts were the attainment of independence in 1980, the introduction of the economic structural adjustment program (ESAP) in 1992, the introduction of the land reform program in 2000 and dollarization of the economy in 2009 (United Nations..., 2009). Independence opened up the country to international trade with the abolition of international trade sanctions (Mumbengegwi, 2002). The introduction of ESAP in 1992 further opened the country to international trade. The government implemented monetary, fiscal, trade, exchange rate and agricultural policy reforms (Sithole 1996). The land reform, introduced around 2000 to address the uneven land distribution between black and white farmers, quickly closed up the economy.

\section{Problem statement}

Maintaining an internal and external balance remains a major challenge in Zimbabwe (Reserve Bank of Zimbabwe, 2014). The internal and external imbalances before 2009 have been reflected by a slow erratic growth in Gross Domestic Product, hyperinflation, foreign exchange shortages and BOP deficits (World Bank, 2016). The dollarization introduced in 2009 was followed by fast, short-run economic growth, but later the country became besieged with liquidity challenges and witnessed sluggish growth rates (AFDB, 2015). Dollarization led to liquidity challenges causing weak aggregate demand that affected economic growth. Fiscal space has greatly diminished due to high taxation levels, successive government budget deficits, and the increase in both domestic and external debt (Reserve Bank of Zimbabwe, 2016a). The domestic debt averaged 162\% in 2013, and increased to an average of $202.4 \%$ of GDP in 2016 (Reserve Bank of Zimbabwe, 2016b). The debt build-up is due to money being borrowed to finance current account deficits, driving an increase in the debt-toGDP ratio (AFDB, 2015). However, the introduction of bond coins and notes in 2014 and 2016, respectively, failed to address the liquidity challenges facing the economy. With the introduction of bond notes, the problem quickly resurfaced as inflation and depreciation of bond notes threatening the economic growth (Reserve Bank of Zimbabwe, 2016a). Depreciation of the local currency was necessary to cure its overvaluation.

The overvalued Zimbabwean dollar, then the U.S. dollar, and now the bond notes are weakening the external sector competitiveness, resulting in severe internal and external imbalances or current account deficits (Reserve Bank of Zimbabwe, 2015). This further discourages foreign direct investment. The presence of current account deficits and/or capital outflows weakens internal liquidity inflows, leading to liquidity problems. The depreciation of bond notes against the U.S. dollar is further affecting the economy.

The internal and external imbalances have negatively affected incentives to produce goods for both the domestic and the export markets (Saungweme, 2012). Both domestic and foreign markets are greatly 
depressed; this has resulted in reduced output and exports in most sectors and increased imports, especially of food. The results have been the mounting trade and current account deficits, sluggish economic growth, and higher unemployment rates. Further, increased government deficits and growing debt have constrained the government's ability to service both domestic and international debt, sustain its real exchange rate policy and provide enough liquidity to oil the economy (World Bank, 2016). Hence, the broad objective of this study is to investigate the response of Zimbabwean tobacco exports to the real exchange rate and real exchange rate volatility in 1980-2019.

Table 1. Research objectives and questions

\begin{tabular}{ll}
\hline $\begin{array}{l}\text { i. Compute Zimbabwe's RER } \\
\text { index }\end{array}$ & $\begin{array}{l}\text { i. How has the Zimbabwean } \\
\text { real exchange rate index } \\
\text { evolved? }\end{array}$
\end{tabular}

ii. Compute Zimbabwe's RER ii. How has the Zimbabwean volatility index RER index volatility evolved?

iii. Estimate the response of tobacco exports to import intensity (world demand) in both the short and long run

iv. Estimate the response of tobacco exports to the RER index in both the short and long run

iii. How have tobacco exports responded to import intensity (world demand) in both the short and long run?

iv. How have tobacco exports responded to the RER index in both the short and long run?

$v$. Estimate the response of tobacco exports to terms of trade in both the short and long run

vi. Estimate the response of tobacco exports to the RER volatility index in both the short and long run

vii. Estimate the response of tobacco exports to dollarization in both the short and the long run

RER - real exchange rate.

Source: own elaboration.

\section{Justification and potential contribution of the study}

Zimbabwe is a small open economy facing intensifying globalization and global effects. Hence, its macro price, the real exchange rate, is becoming increasingly important. The real exchange rate signals how the domestic economy should adjust to the external environment, and maintain both domestic and external balance. Zimbabwe is an agro-based economy, and therefore changes in the real exchange rate correspondingly determine the external competitiveness of agricultural export commodities in the international market, as well as domestic production and domestic growth. Furthermore, changes in the real exchange rate affect input markets causing reduced output and reduced exports. Therefore, any agricultural export instability in Zimbabwe can lead to liquidity challenges, thereby affecting overall economic growth. The real exchange rate index is, however, an unobservable variable, and therefore a lot of care is needed to compute and interpret it.

\section{LITERATURE REVIEW}

The broad objective of this section of the study is to review literature on the response of exports to real exchange rates, the volatility of the real exchange rate, and their impacts on exports. This objective is achieved first by evaluating the evolution of Zimbabwe's economic policies and economic performance from 1980 to 2019. Secondly, a review was carried out of literature concepts of real exchange rates, real exchange rate volatility, and real exchange rate equilibrium. The subsequent sections evaluate the different theories and empirical models applied by researchers in estimating the response of agriculture and overall trade to real exchange rates, real exchange rate volatility and other factors. The final section discusses controversies in the debate on how exports respond to factors listed above.

The evolution of Zimbabwe's macroeconomic policies and performance: 1980-2019

Zimbabwe attained independence in 1980. This led to lifting of international trade sanctions, thereby exposing the economy to international influence. Since 1980, the economy's performance - as reflected by the GDP growth rate - was sporadically marked by high growth rates in the early 1980s. Then, in 1984, a recession struck due to drought. After the drought of 1984, stable economic growth was due to the removal of trade sanctions upon independence, and the opening up of external markets which contributed to the increase in aggregate demand in the economy. In the 1990s, Zimbabwe launched 


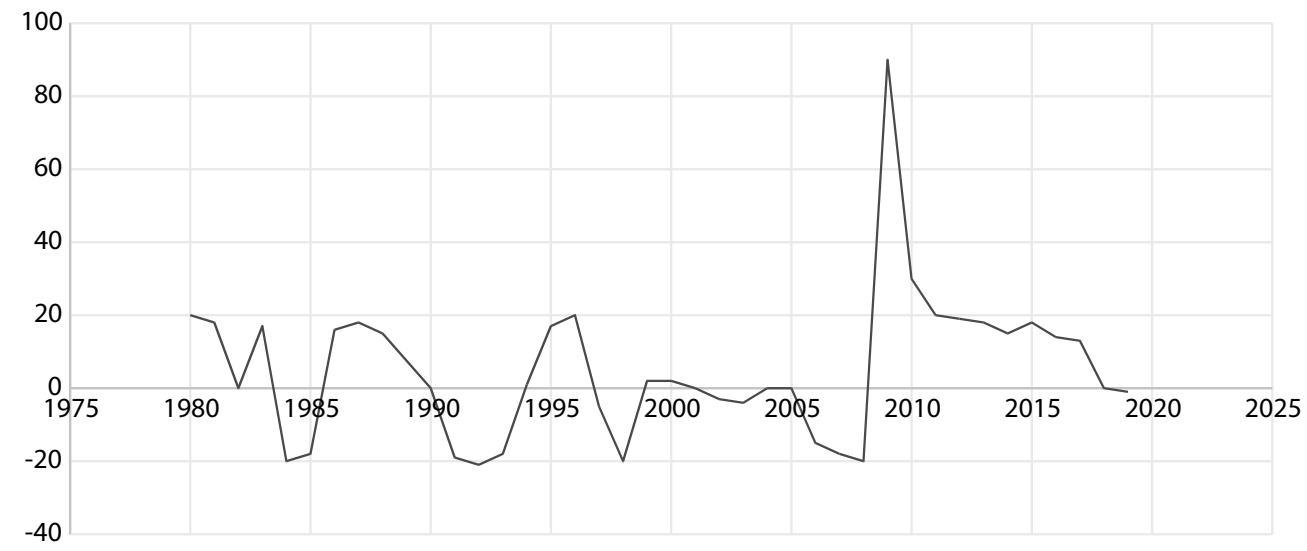

Fig. 1. Nominal GDP growth rate (\%) in Zimbabwe from 1980 to 2019

Source: Global Economy.

the economic structural adjustment program (ESAP) inspired by the World Bank/International Monetary Fund. It was a reaction to the requirement for conditions of rapid economic growth (Mzumara, 2012). Flexible market-oriented macroeconomic policies were adopted. The monetary policy reform included market-based interest rates, parastatal commercialization and liberalization of the financial sector and of the labor market (Mzumara, 2012).

Pricing and marketing reforms were implemented in the agriculture sector. Constrains to private involvement in agriculture were removed together with the elimination of a number of marketing board monopolies (Mumbengegwi, 2002). The pre-arranged policy package had consequences on Zimbabwean economic growth. In 1992, the introduction of ESAP was accompanied by drought. The lowest GDP growth rate was recorded that year, as shown in Figure 1 above. The drought of 1992 affected agricultural production, and consequently had an impact on the overall economic growth. The poor performance of agricultural production severely affected the economy. The economic growth rate after the drought of 1992 was very low and highly erratic, slowing down to $1.9 \%$ per year on average between 1992 and 1996 (Sithole, 1996). The sharp decrease in GDP growth in 1997 and 1998 contributed to growing budget deficits caused by compensating war veterans with an amount equivalent to 3\% of GDP (Buigut, 2015). After the introduction of the land reform in 2000, agricultural production greatly declined and so did economic growth.
Agriculture growth, however, recovered after the introduction of the dollarization policy in 2009. Economic growth also recovered, though it was later affected by tight liquidity conditions in the economy. However, the introduction of bond coins and notes in 2014 and 2016, respectively, failed to address the liquidity challenges facing the economy. With the introduction of local currency and the discontinuation of the dollarization policy, the problem quickly resurfaced as inflation and decline in economic growth.

\section{Concepts of RERs and RER volatility}

The distinction between nominal and real can be applied to both prices and exchange rates in the economy. Changes in nominal exchange rates do not necessarily mean changes in real exchange rates. A nominal exchange rate can depreciate while the real exchange rate appreciates if the country experiences high levels of inflation and other factors. According to Cheng et al. (2012), real appreciation of currency $\mathrm{X}$ is approximately equal to inflation of country $\mathrm{X}$ less nominal depreciation of country X. All those who engage in international transactions are more interested in the real exchange rate than the nominal exchange rate. As a revisit, just like the GDP deflator and producer price index (PPI), RERs are another important macro-price. The GDP deflator measures the price level of all domestically produced goods and services in an economy. The real exchange rate measures how much domestically produced goods and services can be exchanged for goods and services 
produced in another country (Ellis and Ellis, 2001). Real exchange rates are an important concept when analyzing international transactions and the impact of exchange rates on different policy variables (Loretan, 2005). Darvas (2012) mentioned that the real exchange rate serves many purposes, such as assessing the equilibrium value of currency, cost competitiveness, drivers of trade flows, and/or incentives for the reallocation of production between tradable and non-tradable goods sectors.

\section{The theory of RER and RER volatility}

The real exchange rate is more important since it determines the country's internal and external equilibrium position (Kipici and Kesriyeli, 1997). The real exchange rate helps assessing the equilibrium value of a currency, cost competitiveness, drivers of trade flows and/or incentives for the reallocation of production between tradable and the non-tradable goods sectors (Ellis, 2001). Appreciation of the real exchange rate discourages the exportable goods sector, mainly the natural resources sectors, while encouraging the importable goods sector, thereby discouraging economic growth (Nicita, 2013). Resources move to the non-tradable goods sector and strain the exportable goods sector (Mohamad and Jusoff, 2008). Wong (2013) indicated that real exchange rates are volatile and never perfectly predictable. However, in the long run, they are subject to a myriad of simultaneous pressures due to ups and downs in aggregate demand, inflation or deflation cycles, financial panics, political crises, oil shocks, new technologies, abrupt changes in expectations, animal spirits, world pandemics and other factors.

\section{The response of exports to RER, RER volatility and other factors}

There are two major theories that explain the response of exports to factors that affect the export demand: the imperfect and perfect substitute models (Baier and Bergstrand, 2001). Trade equations were specified and estimated based on these two models. The fundamental underlying assumption of the imperfect substitute model is that the analysis is set in a simple two-country model of foreign trade in which each country produces a single traded good which is an imperfect substitute for goods produced domestically in the other country (Osman and Evans, 2005). Conversely, the perfect substitution model assumes perfect substitutability between domestic and foreign goods. Under the perfect substitution model, each country would be only an exporter or an importer of a traded good.

The model has attracted less attention in research as many researchers use the imperfect substitution model based on the Marshallian demand function (Camarero and Tamarit, 2003).

Payne and Mervar (2010) highlighted that the export demand function is specified according to the theory of export demand as a function of the importing country's GDP, exported good's own price and price of imperfect substitutes in the importing market (Cheng et al. 2012). They also pointed that in general, less significant factors (such as unusual occurrences) can be incorporated into the model. The Bank of Uganda (2014) developed a two-country model of international trade based on the imperfect substitution model. The model assumes that the demand for a country's exports is the function of real foreign income and relative prices. This relationship can be formulated as follows:

$$
X^{d}=X^{d}\left(Y^{f}, P x^{f}\right)
$$

where $X^{d}$ is the demand for exports (Zimbabwean tobacco); $Y^{f}$ is foreign income (world income) proxied by world GDP; $P x^{f}=$ relative prices of exportable goods abroad; and $P x^{f}=P_{E} / E P^{f}$ where $P_{E}$ is the price of exportable goods in domestic currency per unit of foreign currency; $E$ is the nominal exchange rate defined as the amount of local currency per unit foreign currency; and $P^{f}$ is the foreign price level in foreign currency.

\section{Empirical evidence of impact of RERs and RER volatility on exports}

The evidence of impact of RERs and RER volatility on exports, trade position and economic growth remains controversial (Lubinga and Kiiza, 2013). Danquah (2014) examined the response of external trade to real exchange rate in Ghana. The study used the ARDL model to analyze the export demand function. The variables were tested for stationarity using the Dickey-Fuller generalized least squares because non-stationary time series data can lead to spurious regression. A further test for cointegration was conducted to choose the appropriate model for the data. The results indicated that in the long run, the response of exports to the real exchange rate was found to be negative. A 10\% appreciation of the real exchange rate was found to reduce exports by $3.6 \%$ in the long run. The results suggested that an appreciation of the real exchange rate caused exports to 
be uncompetitive in the international market. This resulted in deteriorating the trade balance in the long run. In the short run, the real exchange rate had an expected negative sign but was not significant. Hence, the study recommended the government to strengthen the coordination between exchange rate and demand-side policies.

In South Africa, Peter (2013) used the VECM model to assess the impact of real exchange rate volatility on the competitiveness of agricultural exports from 1980 to 2008. Real exports were a function of income from South Africa's trading partners (mainly including European countries), relative prices and real exchange rate volatility. The ADF test was used to test the stationarity of variables. The VECM was used and the authors wondered whether the Engle-Granger test for co-integration and modeling co-integrated systems could have been applied. However, they cited the shortcomings of the model, namely that it could estimate up to one co-integrating relationship between the variables. The results revealed that real exchange rate volatility, foreign income, and relative prices had a positive impact on South African agricultural exports in the short run, but in the long run, the real exchange rate had no significant impact. It is clear at this point that the impact of real exchange rates and real exchange rate volatility on exports remains controversial.

However, it is also essential to examine several issues that surround the theory and computation of nominal or real exchange rates indexes. The absolute Purchasing Power Parity theory relies on the assumption of the law of one price. The law of one price always implies integrated competition markets. However, the spot price of a given commodity will not necessarily be equal in different locations at a given time because of the inability to shift commodities instantaneously from one location to another. The basket of commodities tends to differ between countries, and the price measures across countries are unlikely to be constructed in terms of absolute amounts.

Weighted average bilateral nominal exchange rates are used to assess how the exchange rate of the domestic currency appreciated or depreciated relative to the exchange rate of trading partners compared to a base year. Some researchers, however, refer to the computed index as an effective nominal exchange rate or multilateral nominal exchange rate which might be confusing. This methodological ambiguity has often led researchers to use these terms interchangeably which is sometimes puzzling and difficult to understand.

\section{RESEARCH METHODOLOGY}

The objective of this section is to present research methods and techniques used in evaluating the response of tobacco exports in Zimbabwe to RERs, RERV and other factors. This broad objective is achieved first by presenting the conceptual framework of the response of exports to these variables. The second part describes the steps used in the computation of the RER index. The paper then presents the process of generating the RERV index using GARCH and ARCH models. Thereafter, it provides a model for estimating the response of tobacco exports to RERs and RERV indexes and other factors.

The RER is defined as the nominal exchange rate adjusted for price differential between trading partners. Mathematically, it can be presented as:

$$
\mathrm{RER}=\mathrm{e} \frac{\mathrm{P}_{\mathrm{f}}}{\mathrm{P}_{\mathrm{d}}}
$$

where RER is the real exchange rate index, $\mathrm{e}$ is the bilateral nominal exchange rate, $\mathrm{P}_{\mathrm{f}}$ is the foreign price level and $P_{d}$ is the domestic price level. The decrease in the index based on the above formula represents an appreciation of the RER. The home currency appreciates in real terms. An increase in the index represents a depreciation of the RER. The home currency depreciates in real terms (Kipici and Kesriyeli 1997; Opoku-afari 2004). RER can drop due to three events, i.e. a decline in $\mathrm{P}_{\mathrm{f}}$ , an increase $P_{d}$, and/or a decline in e. All these events can lead to a depreciation of the real exchange rate of the home currency. The RER can increase if $P_{f}$ increases, $P_{d}$ falls and $e$ increases, causing the appreciation of the home RER. However, simultaneous and differential changes in these three factors can lead to indeterminate changes to RERs.

\section{Methods of computing RER, RER volatility and the exports response function}

A chain-linked multilateral real exchange rate index aggregated from individual bilateral real exchange rates with the weighted values for the corresponding years is constructed as follows:

$$
\begin{gathered}
\operatorname{MRER}_{t}=(\mathrm{BRER} 1 t) \mathrm{W} 1 t+(\mathrm{BRER} 2 t) \mathrm{W} 2 t \ldots+ \\
(\mathrm{BRERN} t) \mathrm{WN} t
\end{gathered}
$$

where: BNER is defined as the bilateral nominal exchange rate for Zimbabwe with country $i$ at time $t$. $\mathrm{BRER}_{t}$ is BNER adjusted for price differentials using 
GDP deflators. $\mathrm{W}_{i t}$ is the weight of country $i$ at time $t$. The autoregressive process generates the real exchange rate volatility based on the chain-linked multilateral real exchange rate index as follows:

$$
\Delta \mathrm{RER}_{t}=\alpha_{0}+\sum \mathrm{p}_{i} \partial_{i} \Delta \mathrm{RER}_{t-1}+u_{t}
$$

where $\alpha_{0}$ is a constant, $\partial_{i}$ are coefficients of lagged values of RER and $u_{t} \Omega_{t}-1 \sim \mathrm{N}\left(0, \delta^{2}\right)$ is the error term which is normally distributed with a zero mean and variance $\delta^{2}$. The set of available information at time $t-1$ is denoted by $\left|\Omega_{t}-1\right|$. Tabar-Hashemi (2009) notes that variance is allowed to vary over time, and the idea behind the $\mathrm{ARCH}$ model is to characterize the changes in variance over time. Variance is assumed to be captured by the following autoregressive process:

$$
\delta_{t}^{2}=\chi_{0}+\sum \mathrm{p}_{i=1} \varnothing_{i} \mu_{t-i}^{2}
$$

where $\delta_{t}^{2}$ is the conditional variance of the real exchange rate, $\mu_{t-i}^{2}$ are the squared residuals derived from equation (4), and $\varnothing_{i}$ are the parameters to be estimated. $\varnothing_{i} \geq 0$, this condition is necessary to ensure that the predicted variance is always positive. In equation (4), the current levels of misalignment are determined by the misalignment of the previous levels. Therefore, low or high periods of movements tend to continue. On the other hand, to extend the ARCH model, a GARCH (p, q) process will then be introduced in which $\delta_{t}^{2}$ becomes a function of both $\mu_{t-i}^{2}$ and lagged values of itself. The ARCH term, or the number of autoregressive lags denoted by $p$ and $q$, is the GARCH term (or specifies the number of moving averages used). The conditional variance is then estimated as shown below:

$$
\delta_{t}^{2}=\lambda_{0}+\Sigma_{i=1}^{p} \varnothing_{i} \mu_{t-i}^{2}=\Sigma \mathrm{q}_{i=1} \delta_{i} \sigma_{t-i}^{2}
$$

To have a positive variance, all coefficients in equation (5) must be positive.

The derived export response function based on the imperfect substitution model is applied to the tobacco export response model for Zimbabwe. The model is logarithmized, except for real exchange rate volatility and dollarization because real exchange volatility can take negative values whereas dollarization is a dummy variable. Thus, the tobacco export response model reduces to:

$$
\begin{gathered}
\ln \left(\mathrm{EXPT}_{\mathrm{t}}\right)=\mathrm{b}_{0}+\mathrm{b}_{1} \operatorname{lnRWGDP}_{\mathrm{ft}}+\mathrm{b}_{2} \operatorname{lnRER}_{\mathrm{t}}+ \\
\mathrm{b}_{3} \ln \operatorname{lnOT}_{\mathrm{t}}+\mathrm{b}_{4} \text { RERV }_{\mathrm{t}}+\mathrm{b}_{5} \text { DOL }_{\mathrm{t}}+\mathrm{e}_{\mathrm{t}}
\end{gathered}
$$

Where EXPT is the tobacco export volume during the period $t, \mathrm{RWGDP}_{\mathrm{ft}}$ is the real world gross domestic
Table 2. Prior expectation of the response of tobacco exports to independent variables

\begin{tabular}{lcc}
\hline \multicolumn{1}{c}{ Independent variables } & $\begin{array}{c}\text { Expected } \\
\text { signs }\end{array}$ & $\begin{array}{c}\text { Expected } \\
\text { signs }\end{array}$ \\
\cline { 2 - 3 } & Short run & Long run \\
\hline Real world GDP (LNRWGDP) & - & + \\
Real exchange rate (LNRER) & - & + \\
Terms of trade (LNTOT) & - & + \\
Real exchange rate misalignment & + & - \\
(RERM) & & + \\
Dollarization & - & - \\
Error term (dynamic) & - & + \\
\hline
\end{tabular}

product or import intensity, $\mathrm{RER}_{\mathrm{t}}$ is the real exchange rate within the sample period, TOT $_{t}$ is a measure of the relative price level of export/import prices (proxied for terms of trade), $R E R V_{t}$ is a measure of the real exchange rate volatility, $\mathrm{DOL}_{t}$ is dollarization and $\mathrm{e}_{\mathrm{t}}$ is the error term.

Economic agents take time to respond to new economic conditions. As a consequence, state interventions have different impacts in the short run because of policy time lags. In the long run, economic agents have enough information and time to adjust to market information and conditions. As a result, export activities carried out by rational economic agents will respond to policy changes in the long run, yet economic agents might not respond in the short run. The error correction term is expected to be negative in the short and long run. However, the negative sign on the error correction term (ECT) indicates that the model adjusts back to the equilibrium after an exogenous shock.

\section{Estimation of RER and RER volatility indexes}

This section seeks to compute the real exchange rate and real exchange rate volatility indexes. To achieve this broad objective, the chapter starts by presenting time series data and its sources. The second section computes the real exchange rate index using a timevariant weighting system and GDP deflators for each trading partner. Thirdly, the real exchange rate volatility index is generated using the GARCH and ARCH models. The section concludes by discussing the computed indexes. 


\section{Data and data sources}

This study uses published secondary annual time series data for Zimbabwe, spanning from 1980 to 2019. The data was collected during a period where Zimbabwe has had major inflationary episodes and changes of currency. This compromises the quality, consistency and reliability of data used in this study. The data for weights, exchange rates, real world GDP, and GDP deflators used in computing the real exchange rate index was collected from the World Bank (WB), the International Monetary Fund and the United Nations commodity trade. Data on tobacco exports was collected from the Tobacco Marketing Board. The major problem with this data is the change of currency in 2009 when the country dollarized its economy. Up until 2008, the exchange rate was specified for the Zimbabwean dollar (per unit of foreign currency). After March 2009, it was expressed as USD per unit of foreign currency. The currency has now changed back to Zimbabwean dollar. These changes are confusing and complicated, making both a static and dynamic analysis and interpretation very difficult. Most developing countries face data collection, compilation, and processing challenges, particularly during inflationary periods when prices are dramatically changing (Mohamad and Jusoff, 2008).

\section{Computation of the RER index}

The process of computing the real exchange rate involves several interrelated steps. The first one is the selection of bilateral nominal exchange rates. This study selected ten bilateral nominal exchange rates for major trading partners comprising more than $50 \%$ of Zimbabwean total foreign trade. The three-year time-dependent weights for ten selected major trading partners were calculated, as reported in Table 3 below.

\section{DISCUSSION OF RESULTS, POLICY IMPLICATIONS AND CONCLUSIONS}

This section explores estimation of results, policy implications and conclusions. In order to achieve this broad objective, the first part discusses the real exchange rate and real exchange rate volatility indexes. The second section discuses short-run and long-run tobacco export demand elasticities and dynamics. The final section presents policy implications and recommendations. The chapter concludes with a summary, conclusion and identification of areas of further research.

Table 3. The evolution of weights for Zimbabwe's major trading partners in percentages (\%)

\begin{tabular}{|c|c|c|c|c|c|c|c|c|c|c|c|}
\hline \multirow{2}{*}{ Country } & \multicolumn{11}{|c|}{ Year } \\
\hline & 1988 & 1991 & 1994 & 1997 & 2000 & 2003 & 2006 & 2009 & 2012 & 2015 & 2018 \\
\hline Germany & 11.93 & 7.4 & 8.99 & 8.03 & 9.9 & 3.4 & 6.8 & 2.53 & 3.09 & 2.8 & 2.3 \\
\hline Japan & 7.82 & 9.47 & 9.69 & 9.07 & 7.42 & 2.71 & 4.65 & 2.15 & 1.17 & 2.4 & 0.9 \\
\hline China & 4.48 & 2.74 & 1.68 & 4.96 & 0.59 & 0.14 & 8.89 & 10.7 & 19.88 & 19.9 & 18.03 \\
\hline France & 2.85 & 2.53 & 3.07 & 3.15 & 2.45 & 0.72 & 0.76 & 0.86 & 1.03 & 1.6 & 1.98 \\
\hline South Africa & 35.61 & 37.35 & 49.13 & 39.47 & 41.47 & 20.61 & 56.55 & 64.69 & 54.81 & 56.3 & 58.16 \\
\hline UK & 11.21 & 16.35 & 11.61 & 12.46 & 13.5 & 3.39 & 4.16 & 4.21 & 2.45 & 2 & 2.45 \\
\hline Zambia & 4.55 & 3.3 & 2.85 & 5.04 & 5.86 & 3.79 & 7.49 & 5.09 & 10.26 & 8.6 & 9.6 \\
\hline U.S. & 7.7 & 11.88 & 7.31 & 8.54 & 6.6 & 1.75 & 4.99 & 3.93 & 2.09 & 2.12 & 2.08 \\
\hline Netherlands & 7.84 & 4.2 & 4.26 & 4.97 & 6.87 & 1.94 & 2.42 & 4.11 & 2.11 & 2.12 & 2.1 \\
\hline Italy & 5.98 & 4.78 & 1.39 & 4.26 & 5.35 & 1.21 & 3.38 & 1.72 & 3.09 & 2.16 & 2.4 \\
\hline Total & 100 & 100 & 100 & 100 & 100 & 100 & 100 & 100 & 100 & 100 & 100 \\
\hline
\end{tabular}




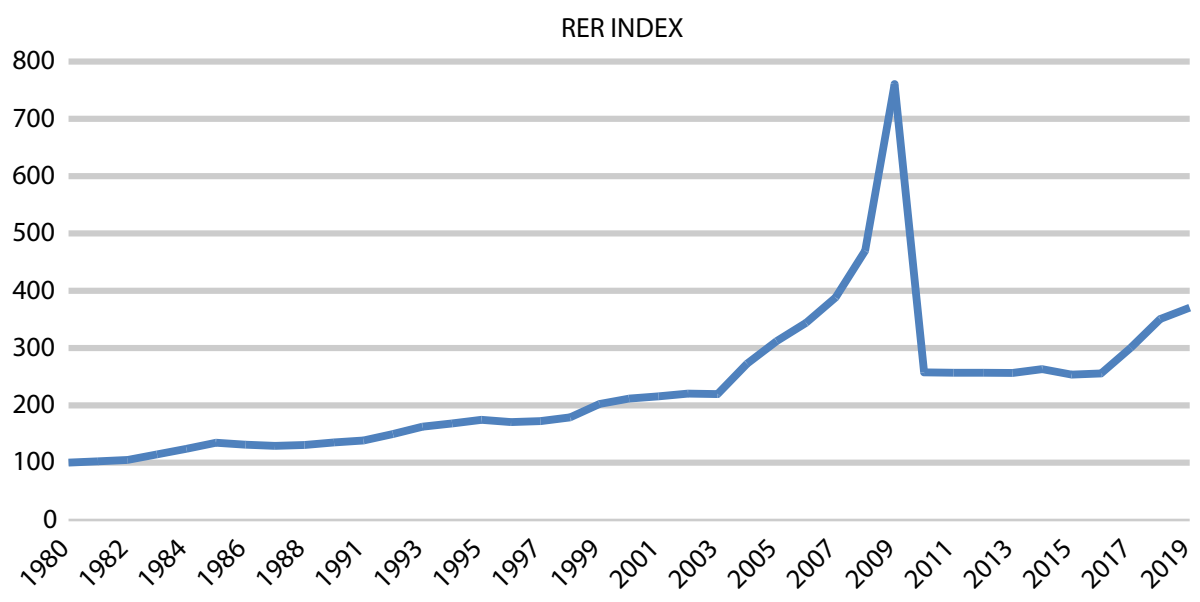

Fig. 2. Zimbabwean real exchange rate index in 1980-2019

\section{Discussion of estimated RERs and RER volatility indexes}

The RER index has been depreciating since 1980, though at a low rate. The RER index depreciated by $39 \%$. This implies that the Zimbabwean dollar depreciated in real terms during that period. The introduction of ESAP in the 1990s marked the beginning of RER index fluctuations. The real exchange rate responded to changes in the exchange rate policy in 1992 and depreciated by $77 \%$ during that period. However, the depreciation was particularly severe in 2000-2008, during the land reform program. The decline in agricultural production affected the supply of foreign currency and caused instability in the foreign exchange market. The RER index greatly depreciated by $545 \%$. The value of the Zimbabwean dollar declined sharply against the value of trading partners' currencies.

It can be shown that the volatility of the real exchange rate was very low in the period just after independence. This can be attributed to the pre-independence fixed exchange rate system adopted by the Zimbabwean government in 1980. The small fluctuations in the exchange

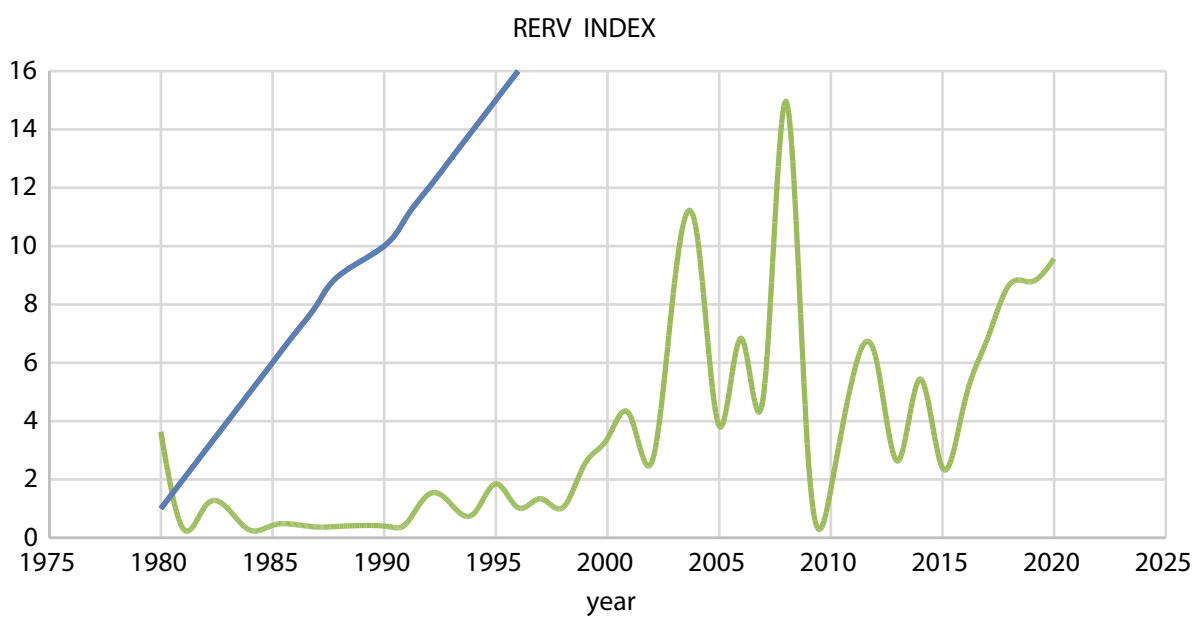

Fig. 3. Real exchange rate volatility index in 1980-2019 
rate imply that it was stable and that the risk associated with its fluctuations was very low. Also, the firms faced only a small risk when entering the international market. Fluctuations in the real exchange rate started in 1992 when ESAP was introduced. This is evidenced by Figure 2 above, and can be attributed to the fact that the government liberalized the fixed exchange rate system, shifting to a market-determined exchange rate. In that period, low volatility of the exchange rate could have promoted foreign trade.

The period from 2000 to 2008 was marked by a highly volatile real exchange rate, as evidenced by the corresponding index. This is the period when Zimbabwe launched a land reform program known for having destabilized agricultural production, a pillar of the Zimbabwean economy (Scoones et al., 2011). The high real exchange rate volatility over that period can be connected to hyperinflation, large balance of payments deficits and great depreciations of the Zimbabwean dollar. The high exchange rate volatility over that period could have affected Zimbabwe's foreign trade. This is because domestic firms would not be willing to participate in foreign markets due to a high risk which can have an adverse effect on their profit margins. Agricultural and non-agricultural export commodities could have been affected by the random movements of the exchange rate. Under the dollarization policy, volatility of the real exchange rate was low compared to the pre-dollarization period. This is because dollarization of the Zimbabwean economy tamed large depreciations of the domestic currency and the rampant hyperinflation. The adoption of the United States dollar as the anchor currency in the economy reduced the volatility of the exchange rate to low levels. A low volatility of the exchange rate encourages domestic firms to participate in foreign markets due to reduced risks associated with exchange rate fluctuations. The recent introduction of bond notes as the local currency has resulted in the rise of exchange rate volatility on the local market.

\section{Results and discussion of the tobacco exports demand function}

The results of the correlation test for tobacco exports, real world GDP (WGDP), real exchange rate (RER), terms of trade (TOT), real exchange rate volatility (RERV) and dollarization are summarized in Table 4 below.

The results of the correlation test reveal that the variables in the model are not correlated.

The variables were further tested for stationarity using the unit root tests. The Augmented Dickey-Fuller (ADF) test is used to check if the variables are stationary at levels $1(0)$. If the probability is above the $5 \%$ level of significance, it indicates that the variables are not stationary. Conversely, if the variables are below the $5 \%$ level of significance, they are stationary. Therefore, the null hypothesis tested is that $H_{0}: \delta=0$ (i.e. that the variable is non-stationary), whereas the alternative hypothesis is that $H_{1}: \delta \neq 0$ (i.e. the variable is stationary) (Odili, 2015). All the variables were found to be nonstationary at levels. Stationarity is indicated by their respective probabilities which are all above the 5\% level of significance, as shown in Table 5 below.

As shown by the results, the null hypothesis that the variables under consideration have a unit root could not be rejected. This means that the variables are not stationary at levels, and are not integrated of order zero

Table 4. Correlation tests

\begin{tabular}{lcccccc}
\hline & LNEXPORTS & LNRWGDP & LNRER & LNTOT & RERV & DN \\
\hline LNEXPORTS & 1 & 0.176 & 0.381 & -0.103 & 0.0920 & 0.0351 \\
LNRWGDP & 0.176 & 1 & 0.136 & -0.072 & 0.056 & -0.435 \\
LNRER & 0.381 & 0.136 & 1 & -0.130 & -0.096 & -0.1107 \\
LNTOT & -0.103 & -0.072 & -0.130 & 1 & -0.088 & 0.0897 \\
RERV & 0.092 & 0.056 & -0.096 & -0.088 & 1 & -0.0340 \\
DN & 0.035 & -0.435 & -0.110 & 0.089 & -0.034 & 1 \\
\hline
\end{tabular}

Source: Eviews Software Computation 2020. 
Table 5. ADF-based unit root tests at levels I (0). LNEXPORTS, LNRWDGP, LNRER, LNTOT and RERV

\begin{tabular}{lcc}
\hline \multirow{2}{*}{ Variables } & With intercept & $\begin{array}{c}\text { With intercept } \\
\text { and trend }\end{array}$ \\
\cline { 2 - 3 } & $\mathrm{I}(0)$ Prob. & $\mathrm{I}(0)$ Prob. \\
\hline LNEXPORTS & 0.4502 & 0.7681 \\
LNRWGDP & 0.8098 & 0.8652 \\
LNRER & 0.0943 & 0.0554 \\
LNTOT & 0.2198 & 0.1997 \\
RERV & 0.1036 & 0.2465 \\
\hline
\end{tabular}

Source: Eviews Software Computation 2020.

$\mathrm{I}(0)$. Table 5 above indicates that even with intercept and trend, the variables under study are still not stationary at levels and are not $\mathrm{I}(0)$. Since the variables are not stationary at levels, all variables are differenced at first level, and further stationary tests are carried out. Stationarity tests for unit roots on differenced data revealed the non-existence of unit roots. The differenced series were found to be stationary. Table 6 below presents the respective probabilities which are all below $5 \%$.

The null hypothesis that the variables have a unit root is rejected in favor of the alternative hypothesis which states that the variables do not have a unit root. Therefore, all variables in the model are stationary at first difference.

Since the level of data integration is known, a cointegration test can be carried out to check for a long-run

Table 6. ADF-based unit root tests for differenced data, I(1). LNEXPORTS, LNRWDGP, LNRER, LNTOT and RERV

\begin{tabular}{lcc}
\hline \multirow{2}{*}{ Variables } & With intercept & $\begin{array}{c}\text { With intercept } \\
\text { and trend }\end{array}$ \\
\cline { 2 - 3 } & I(I) Prob & I(I)Prob \\
\hline LNEXPORTS & 0.0000 & 0.0000 \\
LNRWGDP & 0.0002 & 0.0003 \\
LNERER & 0.0000 & 0.0000 \\
LNTOT & 0.0001 & 0.0002 \\
RERV & 0.0000 & 0.0000 \\
\hline
\end{tabular}

Source: Eviews Software Computation 2020. relationship. Cointegration tests seek to establish any long-run relationship between variables. Given that this data is now stationary at first difference, the Johansen maximum likelihood criteria is used to find the number of cointegrating equations in the model. The Johansen method is used because the variables are integrated of the same order. The cointegration test based on the Johansen maximum likelihood procedure was carried out to establish a long-run relationship, and revealed the existence of such a relationship between the variables. The trace statistic tests the null hypothesis of $r$ cointegrating relations against the alternative of $n$ cointegrating relations ( $n$ is the number of variables in the model where $\left.r=0,1,2, \mathrm{n}^{-1}\right)$. The maximum eigenvalue tests the null hypothesis of $r$ cointegrating relations against the alternative of $r+1$ cointegrating relations for $\mathrm{r}=0$, $1,2, \mathrm{n}^{-1}$ (Odili, 2015). If there is at least one cointegrating equation in the model, both in trace statistic test and in the maximum eigenvalue test, the null hypothesis is rejected at $5 \%$ in favor of the alternative hypothesis. Table 7 below summaries these results.

In both (trace and maximum eigenvalue) tests for cointegration, the null hypothesis that no cointegration exists among variables is rejected at the $5 \%$ level of significance. The alternative hypothesis (that at least 1 cointegrating equation exists among variables) is accepted. This indicates that there is a long-run relationship or association between the variables. Both tests indicated that there is 1 cointegrating equation at the $5 \%$ level of significance.

\section{Specification and estimation of the VECM}

Since the data revealed the absence of autocorrelations among variables and demonstrated that all variables are integrated of order 1 and have at least one cointegrating relationship, it is now possible to specify and estimate a vector error correction model and to compute both long-run and short-run elasticities and the error correction term. A VECM is recommended since variables are integrated of the same order and are cointegrated (Obayelu and Salau 2010). According to Odili (2015), the VECM is used if a set of variables is found to have one or more cointegrating vectors, since it incorporates both short-run and long-run effects of variables.

In order to specify the VECM, lag lengths of both the independent (p) and independent variables (q) must be known. The optimal lag length of variables included in the VECM model is obtained from the selection 
Table 7. Cointegration test for LNEXPORTS, LNR WDGP, LNRER, LNTOT, RERV and DN

\begin{tabular}{|c|c|c|c|c|}
\hline Hypothesized & & Trace & 0.05 & \\
\hline \multicolumn{5}{|c|}{ Unrestricted cointegration rank test (trace) } \\
\hline No. of CE(s) & Eigenvalue & Statistic & Critical value & Prob.** \\
\hline None * & 0.918058 & 149.0147 & 95.75366 & 0.0000 \\
\hline At most 1 & 0.532483 & 66.45733 & 69.81889 & 0.0900 \\
\hline At most 2 & 0.471978 & 41.36677 & 47.85613 & 0.1773 \\
\hline At most 3 & 0.268750 & 20.29240 & 29.79707 & 0.4032 \\
\hline At most 4 & 0.244401 & 9.963423 & 15.49471 & 0.2835 \\
\hline At most 5 & 0.021444 & 0.715337 & 3.841466 & 0.3977 \\
\hline Hypothesized & & Max-Eigen & 0.05 & \\
\hline \multicolumn{5}{|c|}{ Unrestricted cointegration rank test (maximum eigenvalue) } \\
\hline No. of CE(s) & Eigenvalue & Statistic & Critical value & Prob.** \\
\hline None * & 0.918058 & 82.55736 & 40.07757 & 0.0000 \\
\hline At most 1 & 0.532483 & 25.09056 & 33.87687 & 0.3789 \\
\hline At most 2 & 0.471978 & 21.07437 & 27.58434 & 0.2717 \\
\hline At most 3 & 0.268750 & 10.32898 & 21.13162 & 0.7133 \\
\hline At most 4 & 0.244401 & 9.248086 & 14.26460 & 0.2661 \\
\hline At most 5 & 0.021444 & 0.715337 & 3.841466 & 0.3977 \\
\hline
\end{tabular}

The trace test indicates 1 cointegrating eqn(s) at the 0.05 level.

* Denotes rejection of the hypothesis at the 0.05 level.

Source: Eviews Software Computation 2020.

criteria based on the Akaike's Information Criteria (AIC), Schwartz-Bayesian Criteria (SBC) and the Hannan-Quinn information criterion. These models indicate the lowest value; and the lower the value, the better the model. If more than one criterion suggests the same number of lags, that lag number is selected. Table 8 below summarizes the result of the estimate.
The table indicates that the optimum lag length is one for the specified vector error correction model. We can now specify the VECM for the estimation of the short run, long-run and the error correction term of the tobacco export demand function.

Given the lag information, the VECM is also tested for its statistical properties of serial correlation,

Table 8. Lag length selection criteria. LNEXPORTS, LNRWGDP, LNRER, LNTOT, RERV and DN

\begin{tabular}{ccccccccc}
\hline lag & LL & LR & df & $p$ & FPE & AIC & HQIC & SBIC \\
\hline 0 & -1773.89 & & & & $6.2 \mathrm{e}+40$ & 108.115 & 108.267 & 108.568 \\
1 & -1653.41 & 240.96 & 25 & 0.000 & $7.0 \mathrm{e}+38$ & $102.328^{*}$ & $102.005^{*}$ & $103.811^{*}$ \\
2 & -1607.98 & $90.862^{*}$ & 25 & 0.000 & $6.5 \mathrm{e}+37^{*}$ & 103.09 & 103.345 & 103.835 \\
\hline
\end{tabular}

Source: Eviews Software Computation 2020. 
heteroscedasticity, normality and stability. The model is tested for serial correlation using the Breusch-Godfrey serial correlation LM test. The results are reported in Table 9 below.

Table 9. Serial correlation test

\begin{tabular}{llll}
\hline \multicolumn{4}{c}{ Breusch-Godfrey serial correlation LM test } \\
\hline F-statistic & 2.843373 & Prob. F(1,24) & 0.1047 \\
Obs*R-squared & 3.495511 & Prob. Chi-Squared(1) & 0.0615 \\
\hline
\end{tabular}

Source: Eviews Software Computation 2020.

The statistics reveal the absence of autocorrelation by rejecting the existence of autocorrelation based on the Breusch-Godfrey serial correlation LM test. The Fstatistic and chi-squared probabilities are all above 5\%, indicating that the null hypothesis on the absence of serial correlation cannot be rejected. Based on the above results, the model has no serial correlation. The Q-statistic also confirms the absence of serial correlation in the estimated model.

Furthermore, the model was checked for the presence of heteroscedasticity using the Breusch-Pagan-Godfrey test. If the probability of the F-statistic is above $5 \%$, the null hypothesis on the absence of heteroscedasticity is accepted. Conversely, if the probability is below 5\%, the alternative hypothesis on the presence of heteroscedasticity in the model is accepted. Table 10 below summarizes the results.

Table 10. Heteroscedasticity test

\begin{tabular}{lrc}
\hline \multicolumn{3}{c}{ Heteroscedasticity Test: Breusch-Pagan-Godfrey } \\
\hline F-statistic & 1.222551Prob. F(11,21) & 0.3319 \\
Obs*R-squared & 12.88276 Prob. Chi-Squared(11) & 0.3011 \\
Scaled explained SS & 9.024176Prob. Chi-Squared(11) & 0.6197 \\
\hline
\end{tabular}

Source: Eviews Software Computation 2020.

The statistics reveal the absence of heteroscedasticity based on the Breusch-Pagan-Godfrey test. The results indicate that the F-statistic's probability is above the $5 \%$ level of significance, indicating that the null hypothesis on the absence of heteroscedasticity in the model cannot be rejected. Hence, the model is free from heteroscedasticity.

The vector error correction model is further tested for normality to find if the model is normally distributed. If the probability is below $5 \%$, the null hypothesis on the model's normal distribution is rejected. Conversely, if the probability is above $5 \%$, the null hypothesis is accepted. The distribution of the vector error correction model is presented in the appendix. The probability $(0.62459)$ is above the $5 \%$ level of significance. Thus, the null hypothesis on the model's normal distribution cannot be rejected; the model is normally distributed at the $5 \%$ level of significance. Finally, the model was tested for stability. These tests are used to examine the stability of long-run parameters together with the short-run movements for the equations (Alimi, 2014). The stability of the estimated error correction model should be empirically investigated (Pahlavani et al., 2005). The stability of the model is tested using the cumulative sum (CUSUM) and cumulative sum squares (CUSUMSQ) tests. If the plots of CUSUM and CUSUMSQ statistics are within the critical bounds at the $5 \%$ level of significance, the null hypothesis that the coefficients in the model are stable is accepted. However, if the plots of CUSUM and CUSUMSQ statistics are outside the critical bounds at the 5\% level, the null hypothesis that all coefficients in the model are stable is rejected (Berthou, 2008). CUSUM and CUSUMSQ statistics are presented in the appendix. The plot of cumulative sum (CUSUM) and cumulative sum squares (CUSUMSQ) stays within the critical 5\% boundary. Hence, the null hypothesis that the regression equation is correctly specified cannot be rejected. Therefore, this further confirms the existence of a longrun relationship between variables and the stability of the model's coefficients. The above results therefore imply that the model can be used for hypothesis testing and forecasting, since the vector error correction model is normally distributed with classical statistic properties.

The VECM specified below summarizes the estimated long-run elasticities. The estimated long-run cointegrating equation is as follows:

$$
\begin{gathered}
\ln \text { EXPORTS }=-0.056819+77.6279 \ln \mathrm{RWGDP}_{\mathrm{t}-1}- \\
2.140 \ln \mathrm{RER}_{\mathrm{t}-1}-72.10862 \ln \mathrm{TOT}_{\mathrm{t}-1}+2.40 \mathrm{RERV}_{\mathrm{t}-1}+ \\
0.878164 \mathrm{Dn}_{\mathrm{t}-1}
\end{gathered}
$$


Table 11. Results of short-run elasticities and dynamics of the VECM

\begin{tabular}{lcccc}
\hline \multicolumn{1}{c}{ Header } & Coefficient & Std. error & t-Statistic & Prob. \\
\hline LNEXPORTS (-1) & -0.442579 & 0.069106 & -6.404343 & $0.0000^{*}$ \\
LNRWGDP (-1) & -3.174855 & -27.86504 & -0.113937 & 0.9102 \\
LNRER (-1) & $4.92 \mathrm{E}-12$ & $2.24 \mathrm{E}-12$ & 2.192393 & $0.0379^{* *}$ \\
LNTOT (-1) & 9.129417 & 3.000867 & 3.042260 & $0.0055^{*}$ \\
RERV (-1) & $-3.26 \mathrm{E}-11$ & $8.74 \mathrm{E}-12$ & -3.734956 & $0.0010^{*}$ \\
DON (-1) & -4.605568 & 1.653934 & -2.784614 & $0.0101^{* *}$ \\
Error correction term & -0.194986 & 0.03745 & -5.20679 & $0.0000^{*}$ \\
(ECT) -0.194986 & & & & \\
0.0000 & & & 3.207273 \\
R-squared & 0.903540 & Mean dependent var & 3.284633 \\
Adjusted R-squared & 0.876531 & S.D. dependent var & 3.647188 \\
S.E. of regression & 1.127105 & Akaike info criterion & 3.406466 \\
Sum of squared resid & 31.75914 & Schwarz criterion & 1.380898 \\
Log likelihood & -46.19258 & Hannan-Quinn criter. & \\
F-statistic & 33.45335 & Durbin-Watson stat & \\
Prob(F-statistic) & 0.000000 & & \\
\hline
\end{tabular}

* At the $1 \%$ level of significance.

** At the $5 \%$ level of significance.

Source: Eviews Software Computation 2020.

The estimated long-run cointegrating equation revealed that the coefficients of RER, terms of trade and real exchange rate volatility were significant in the long run while those of dollarization and real world GDP were not. The coefficients of variables used in the cointegration equation are presented in the appendix.

The VECM further estimates short-run elasticities, as shown in Table 11 below together with the dynamics of the vector error correction model.

The model is properly fitted with $87.6 \%$ adjusted Rsquared; the Prob(F-statistic) is also significant at the $1 \%$ level. The results indicate that the model is specified correctly.

\section{World GDP}

The results of the tobacco export demand function revealed that tobacco exports were found to have a negative insignificant response at a level of $32 \%$ to a $10 \%$ increase in real world GDP in the short run, and a positive insignificant response at a level of $77 \%$ to a $10 \%$ increase in real world GDP in the long run. The null hypothesis that the response of tobacco exports to an increase in import intensity is negative in the short run and positive in the long run is rejected since real world GDP was found to be insignificant in both the short and long run. The results suggest that the response of tobacco exports to an increase in global economic downturn or recession is negative and insignificant in the short run, and hence fails to explain any variation in tobacco exports. Again, the response of tobacco exports to an increase in real world GDP is positive but insignificant to explain the variation in tobacco exports in the long run.

\section{Real Exchange Rate}

Tobacco exports are found to have a positive response at a level of $49 \%$ to a $10 \%$ depreciation in the RER in the short run. The alternative hypothesis that tobacco exports respond positively to RER depreciation in the short run is accepted. Tobacco exports have a negative response at a level of $24 \%$ to a $10 \%$ appreciation or 
decrease in the RER in the long run. The null hypothesis that tobacco exports respond negatively to an appreciation of the RER index is accepted. This implies that the depreciation of the RER has resulted in the depreciation of the Zimbabwean dollar and then of the United States dollar in real terms against currencies of trading partners. The depreciation of the local currency makes domestically produced goods cheap compared to those produced abroad. This improves export competitiveness and could be the reason behind the positive impact on tobacco exports in the short run. Therefore, a depreciation of the RER in the short run has a positive impact on the demand for tobacco exports in the international market.

Huchet-Bourdon and Korinek (2011) mentioned that short-run effects of exchange rate levels on trade do not normally follow a specific pattern. However, short-run effects can be tested for the existence of a JCurve effect which means that the an increase or depreciation in the real exchange rate is associated with a deterioration in the trade balance in the short run. This is because immediately following RER depreciation, the volume of trade will remain unchanged due to the recognition of the adjustment period by importing countries (Ali et al., 2015). However, the current study of the response to RER does not confirm the presence of the J-Curve phenomenon in the short run. Nevertheless, in the long run, a negative response of tobacco exports to RER appreciation or decrease leads to an appreciation of the Zimbabwean dollar and then of the United States dollar in real terms. An appreciation of the domestic currency increases export prices, leading to a loss of external competitiveness of exported goods. This could be the reason why the appreciation of the RER had a negative impact of $24 \%$ on tobacco exports in the long run. The same long-run effect was found by Danquah (2014): the RER was negatively related to exports in Ghana. However, in the current study, the long-run response of tobacco exports to RER confirms the presence of the J-Curve effect. It states that the long-run appreciation of the domestic currency in real terms harms exports due to the recognition of the adjustment period by importing countries searching for alternatives where goods are cheap (Yazici, 2006). Hence, the appreciation of the Zimbabwean dollar and then of the USD in real terms could have negatively affected the demand for tobacco exports in the international market.

\section{Terms of Trade (TOT)}

Tobacco exports are found to have a positive response at a level of $91 \%$ to a $10 \%$ increase in terms of trade (TOT) in the short run. The alternative hypothesis that tobacco exports respond positively to an increase in TOT in the short run is accepted. In the long run, the response of tobacco is negative at a level of ca. $721 \%$ to a $10 \%$ reduction in TOT. The alternative hypothesis that tobacco exports respond negatively to TOT reduction in the long run is accepted. A positive commodity-market-specific shock or a positive world demand shock can increase the demand for commodities in global markets and bid up their prices around the world. Favorable export prices encourage crop production by firms and individual farmers, thereby increasing tobacco export volumes to the international market. Again, it implies that in the short run, tobacco farmers are highly responsive to an increase in world commodity prices. Therefore, an increase in export prices could act as an incentive for tobacco production in the short run. In the long run, the negative response of tobacco exports to a reduction in TOT can be the result of a negative commodity-marketspecific shock or a negative world demand shock that can reduce the demand for commodities in the world markets. As a result, commodity prices in the world markets decline. Unfavorable export prices discourage firms and individual farmers from crop production in developing countries like Zimbabwe, thereby reducing the volume of tobacco exports to the international market.

\section{Real exchange rate volatility}

Tobacco exports are found to have a negative response at a level of $33 \%$ to a $10 \%$ increase in RER volatility in the short run. The alternative hypothesis that tobacco exports respond negatively to an increase in RER volatility in the short run is accepted. In the long run, tobacco exports respond positively at a level of ca. $22 \%$ to a $10 \%$ increase in RER volatility. The alternative hypothesis that tobacco exports respond positively to an increase in RER volatility in the long run is accepted. The results suggest that volatility of real exchange rates (especially including overvaluations attributable to unsustainable monetary and fiscal policies) have had negative impacts on tobacco export performance. The increase in RER volatility could have made tobacco exports uncompetitive in the international market due to an overvalued local currency. Further deviation of the 
real exchange rate from its equilibrium values also indicates that the exchange rate was very volatile, thereby discouraging tobacco exports in the short run. A higher degree of exchange rate volatility could reduce trade volumes because higher fluctuations in the exchange rate pose a high risk on profits. Risk-averse firms and risk-neutral producers reallocate resources away from high-risk global markets to low-risk domestic markets (Oiro and Otieno, 2015). This therefore means that the greater the volatility of the exchange rate in the short run, the smaller the exports of more risk-averse exporters in the short run. Indeed, some risk-averse firms could have exited the foreign market due to exchange rate fluctuations. Further, it implies that the importing countries in the world market are highly responsive to short-run movements in the real exchange rate. Hence, RER volatility can affect demand for tobacco exports in global markets.

\section{Dollarization}

Tobacco exports are found to have a negative response at a level of $46 \%$ to the lack of dollarization in the short run, and a positive insignificant response at a level of $88 \%$ to the introduction of dollarization in the long run. The null hypothesis that the response of tobacco exports to the introduction of dollarization is negative in the short run and positive in the long run was accepted in the short run and rejected in the long run. This means that the introduction of dollarization does not have a significant short-run impact on tobacco exports. This might be because in the short run, economic agents were adjusting to the new policy intervention. Hence, the variation in exports could be explained by other factors. However, in the long run, the introduction of dollarization is not significant and hence cannot explain the variations in tobacco exports.

Again, it implies that the variation in tobacco exports can be attributed to other factors in the economy. However, Thaver and Bova (2014) found the same result in the short run but a different one in the long run. Dollarization had a negative impact on Ecuador's exports in both the short and long run. The decrease in the lagged values of tobacco exports was found to have a negative response to tobacco exports. A $10 \%$ decrease in the lagged values of tobacco exports was found to have a $44 \%$ negative effect on tobacco exports. In the very short run, tobacco export volumes can be inelastic to changes in tobacco export prices.
However, a short-run period could be enough for tobacco exports to adjust to changes in tobacco export prices. A decline in tobacco export prices due to a decrease in world demand for tobacco could reduce the output and export of tobacco. It also implies that when other firms exit the foreign sector due to lower tobacco export prices, other firms follow suit, leading to reduced output for the export market. The coefficient on the error correction term (ECT) is found to be significant and negative and not lower than -2 , which further confirmed the existence of a long-run relationship between the variables (Odili, 2015). This indicates that the model adjusts quickly back to the equilibrium at a rate of $195 \%$ following an exogenous shock within a year.

\section{Policy implications of the estimated results}

The real exchange rate appreciation was found to negatively affect tobacco exports in the long run. To restore competitiveness of agriculture-based commodities like tobacco under the dollarization policy, the government can devalue the real exchange rate. Devaluation of the real exchange rate can restore competitiveness of tradable goods like tobacco through adjusting for inflation. This is achieved by lowering production or wage costs and improving productivity without lowering the nominal exchange rate value. The above can reduce prices in input markets, lowering the production cost for both individual farmers and firms engaged in the production of tobacco for export markets. The reduction in terms of trade was found to have a negative effect on tobacco exports in the long run. The government can improve the terms of trade by increasing tax on importable goods and simultaneously putting in place policies that encourage local industry growth. The real exchange rate volatility was found to depress tobacco exports in the short run. Hence, the government can adopt other mechanisms to reduce uncertain movements of the exchange rate. For example, the government can establish an operating environment which enables hedging of export sales through forward sales in foreign currency. Also, the dollarization policy was found to have a negative impact on tobacco exports in the short run. Therefore, the government can increase domestic interest rates to attract foreign investment. The resulting capital inflows can ease liquidity challenges in the economy and allow the farmers to access funds to finance agricultural operations. 


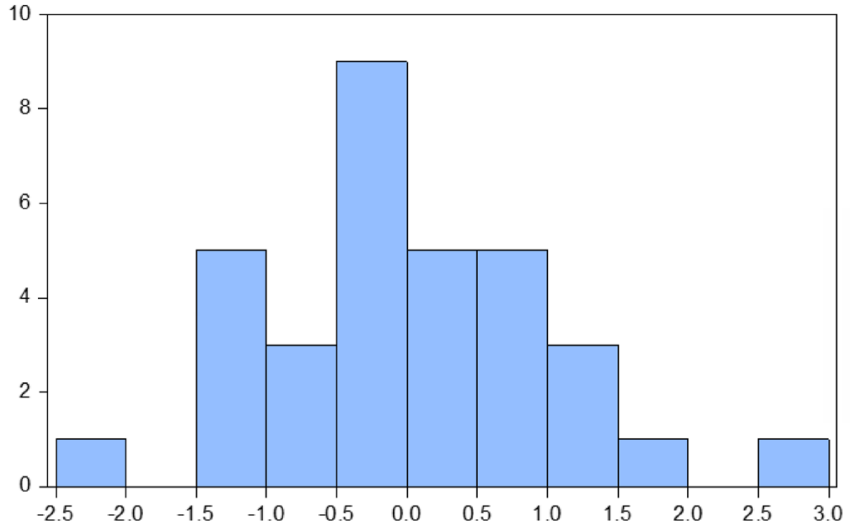

\begin{tabular}{|lc|}
\hline \multicolumn{2}{|l|}{ Series: Residuals } \\
Sample 1983 2015 \\
Observations 33 \\
Mean & $1.77 \mathrm{e}-16$ \\
Median & -0.036384 \\
Maximum & 2.751828 \\
Minimum & -2.185734 \\
Std. Dev. & 0.996229 \\
Skewness & 0.350018 \\
Kurtosis & 3.441050 \\
& \\
Jarque-Bera & 0.941290 \\
Probability & 0.624599 \\
\hline
\end{tabular}

Fig. 4. Normal distribution of the vector error correction model Source: Eviews Software Computation 2020.

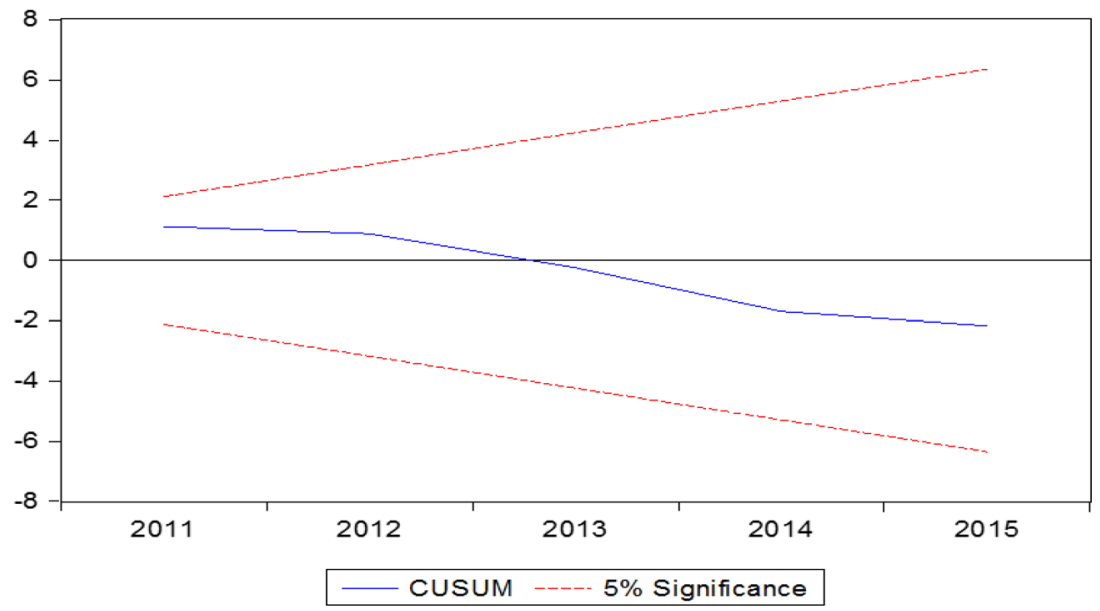

Fig. 5. Cumulative sum (CUSUM) test

Source: Eviews Software Computation 2020.

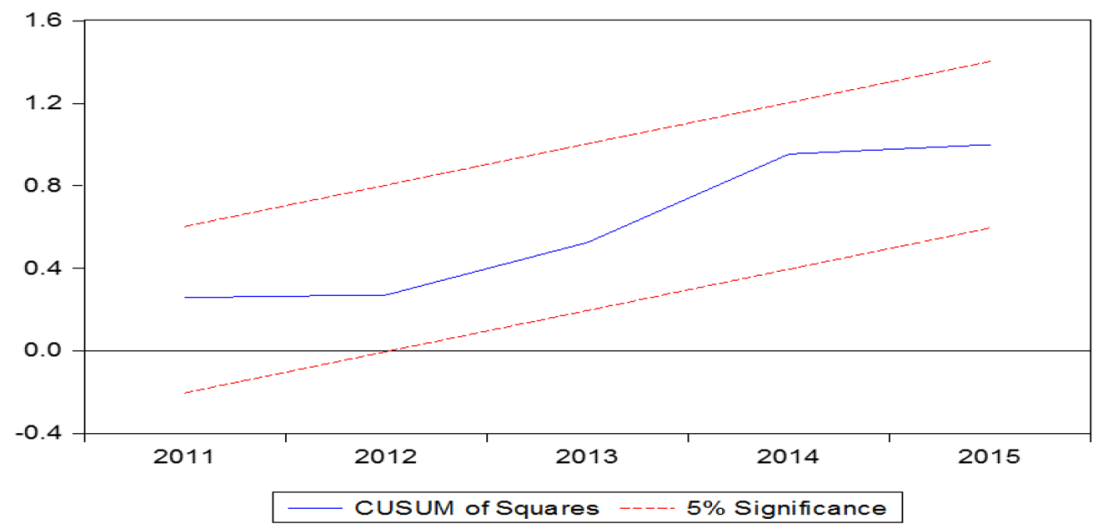

Fig. 6. Cumulative sum squares (CUSUMSQ) test Source: Eviews Software Computation 2020. 
Table 12. Results of long-run elasticities of the vector error correction model

\begin{tabular}{lc}
\hline \multicolumn{1}{c}{ Variables: } & Cointegrating Equation \\
\hline LNEXPORTS (-1) & 1.000000 \\
LNRWGDP $(-1)$ & -77.6279 \\
& {$[-1.04]$} \\
LNRER(-1) & $2.14 \mathrm{E}-10^{* *}$ \\
& $(2.3 \mathrm{E}-11)$ \\
& {$[9.36960]$} \\
LNTOT(-1) & $72.10862 * *$ \\
& $(8.29232)$ \\
RERV $(-1)$ & {$[8.69583]$} \\
& $-2.40 \mathrm{E}-10^{* *}$ \\
& $(2.2 \mathrm{E}-11)$ \\
DON $(-1)$ & {$[-11.0776]$} \\
& -0.878164 \\
& $(0.94282)$ \\
& {$[-0.93142]$} \\
& 0.056819 \\
\hline
\end{tabular}

** Significant at the 5\% level.

Source: Eviews Software Computation 2020.

\section{CONCLUSION AND AREAS FOR FURTHER RESEARCH}

Under the dollarization regime, devaluation of the real exchange rate can restore competitiveness of tradable goods like tobacco. This can be achieved by lowering production or wage costs and improving productivity without lowering the nominal exchange rate value. The introduction of the local currency resulted in real exchange rate depreciation and boosted inflation. Therefore, the government is advised to first address the macroeconomic fundamentals before introducing local currency. Otherwise, the economy will selfdollarize, rendering de-dollarization efforts impractical. The reintroduction of the multicurrency regime would be an alternative route but should be supported by high export growth to ease liquidity challenges in the economy. It is, however, important to craft policies that stabilize the exchange rate, encourage investment and industry production for any monetary policy to be effective. There is need to carry out further research on exchange rate misalignment and investigate its effect on agricultural export commodities in Zimbabwe. Further, there is also need for research on the impact of real exchange rate and real exchange rate volatility on economic growth in Zimbabwe. This will help the government to design exchange rate policies that can improve external sector performance and drive overall economic growth.

\section{REFERENCES}

Ali, A., Johari. F., Alias, M. (2015). On The J-Curve Theory: The Literature and Further Proposed Improvements. Economy, 2(4), 64-70.

Danquah, B.A. (2014). The Effects of Exchange Rate on Ghana's External Trade. British J. Econ. Fin. Manag. Sci., 9(1), 48-68.

Alimi, R.S. (2014). ARDL Bounds Testing Approach to Cointegration: A Re- Examination Of Augmented Fisher Hypothesis In An Open Economy. Asian J. Econ. Model., 2(2), 103-114.

Baier, S.L., Bergstrand, J.H. (2001). The Growth of World Trade- Tarrifs, Transport Costs, and Income Similarity. J. Int. Econ., 5(53), 1-27.

Bank of Uganda (2014). Does Real Effective Exchange Rate Volatility matter for Uganda's Flowers Exports? A Cointegrated VECM Approach, Kampala.

Buigut, S. (2015). The effect of Zimbabwe's Multi-Currency Arrangement on Bilateral Trade: Myth Versus Reality. Int. J. Econ. Fin. Iss., 5(3), 690-700.

Camarero, M., Tamarit, C. (2003). Estimating exports and imports demand for manufactured goods: The role of FDI. Jaume I University.

Cheng, K.M., Kim, H., Thompson, H. (2012). The real exchange rate and the balance of trade in US tourism. Int. Rev. Econ. Fin., 25, 122-128.

Darvas, Z. (2012). A tale of three countries: recovery after banking crises (No. MT-DP-2012/2). IEHAS Discussion Papers.

Ellis, L., Ellis, L. (2001). Measuring the real exchange rate: Pitfalls and practicalities (pp. 2001-2004). Reserve Bank of Australia.

Government of Zimbabwe (2016). The 2016 National Budget Statement, Harare. Retrieved Oct 27 2016 from: www. dpcorp.corp.co.zw/assets

Kipici, A., Kesriyeli, M. (1997). The Real Exchange Rate Definitions and Calculations. Central Bank of the Republic of Turkey. 
Loretan, M. (2005). Indexes of the Foreign Exchange Value of the Dollar, Washington DC.

Lubinga, M.H., Kiiza, B. (2013). Exchange Rate Uncertainty and Bilateral Trade Flows: Insights from Uganda. Bus. Econ. Res., 3(1), 227-239.

Mohamad, S., Jusoff, H.K. (2008). Exchange rates and export growth in Asian economies. Asian Soc. Sci., 4(11), 30-36.

Mumbengegwi, C. (2002). Macroeconomic and Structural Adjustment Policies In Zimbabwe. Palgrave Macmillan.

Mzumara, M. (2012). An overview of Zimbabwe's macroeconomic environment. Int. J. Econ. Res., 3(1), 32-68.

Nicita, A. (2013). Exchange Rates, International Trade and Trade Policies. Int. Econ., 135-136(56), 47-61.

Nyanga, T., Sibanda, R., Kruger, J. (2020). Obstructions to Job Satisfaction: Voices of Small to Medium Enterprise Employees in the Manufacturing Industry in Zimbabwe. Bus. Excell. Manag., 10(1), 16-30.

Obayelu, A.E., Salau, S. (2010). Agricultural Response to Prices and Exchange Rate in Nigeria: Application of CoIntegration and Vector Error Correction Model (VECM). J. Agric. Sci., 1(2), 73-81.

Odili, O. (2015). Real Exchange Rate Volatility, Economic Growth and International Trade in an Emerging Market Economy: Evidence from Nigeria. Int. J. Acad. Res. Bus. Soc. Sci., 5(7), 179-201.

Oiro, M.O. (2015). Real Exchange Rate Volatility and Exports in Kenya: 2005. J. World Econ. Res., 4(5), 115-31.

Opoku-Afari, M. (2004). Measuring the Real Effective Exchange Rate (REER ) in Ghana. Nottingham. Retrieved from https://www.nottingham.ac.uk

Osman, M.A., Evans, S.R. (2005). Time Series Analysis of the Somalian Export Demand Equations: A Co-integration Approach. J. Econ. Soc. Res., 4(2), 71-92.

Pahlavani, M., Wilson, D., Worthington, A.C. (2005). TradeGDP Nexus in Iran: An Application of the Autoregressive Distributed Lag (ARDL) Model School of Economics and Information Systems. Am. J. Appl. Sci., 2(7), 1158-1165.

Payne, J.E., Mervar, A. (2010). Research note: The tourismgrowth nexus in Croatia. Tour. Econ., 16(4), 1089-1094.
Reserve Bank of Zimbabwe (2014). Quarterly Economic Review: Zimbabwe. Harare. Retrieved Oct $20^{\text {th }} 2016$ from: www.rbz.co.zw/assets/quarterlyeconomic-review-december-2014-final.pdf

Reserve Bank of Zimbabwe (2016a). 2016 Mid-Term Monetary Policy Statement. Retrieved from: www.rbz.co.zw/ monetarypolicy.html Accessed 20 October 2016

Reserve Bank of Zimbabwe (2016b). Monetary Policy Statement, Economic Transformation Through Transparency and Accountability. (January): 1-92. Retrieved Oct $20^{\text {th }}$ 2016 from: www.rbz.co.zw/monetary-policy.html

Saungweme, T. (2012). Trade Dynamics in Zimbabwe (19802012). Rus. J. Agric. Soc.-Econ. Sci., 10(22), 31-34.

Scoones, I., Marongwe, N., Mavedzenge, B., Murimbarimba, F., Mahenehene, J., Sukume, C. (2011). Zimbabwe's land reform: A summary of findings. Brighton, IDS.

Sithole, G. (1996). Analysis of Policy Reform and Structural Adjustment Programs in Zimbabwe With Emphasis on Agriculture and Trade. Washington, D.C.

Thaver, R.L., Bova, C. (2014). An Estimation of Ecuador's Export Demand Function with the Us. Int. J. Bus. Fin. Res., 8(1), 89-102.

Tobacco Industry and Marketing Board (2015). 2015 Annual Statistical Report. Retrieved Oct $27^{\text {th }} 2016$ from: http:// www.timb.co.zw.106

Trade Economics (2020). Zimbabwe GDP per capita. Retrieved April 30 2020 from: https://tradingeconomics. com/zimbabwe/gdp-per-capita

United Nations Development Programme (2009). Foreign Trade, Competitiveness and the Balance of Payments. Harare.

Wong, H.T. (2013). Real exchange rate misalignment and economic growth in Malaysia. J. Econ. Stud., 40(3), 298-313.

World Bank (2016). Zimbabwe Economic Update, Harare. Retrieved Oct $27^{\text {th }} 2016$ from: www.worldbank.org

Yazici, M. (2006). Is the J-curve effect observable in Turkish agricultural sector? J. Cent. Eur. Agric., 7(2), 319-322. 